\title{
Uporaba matematičkih udžbenika s obzirom na inicijalno obrazovanje učitelja
}

\author{
Vlatka Domović
}

Učiteljski fakultet, Sveučilište u Zagrebu, Hrvatska e-mail:vlatka.domovic@ufzg.hr

\section{Dubravka Glasnović Gracin}

Učiteljski fakultet, Sveučilište u Zagrebu, Hrvatska e-mail:dubravka.glasnovic@ufzg.hr

\author{
Lana Jurčec \\ Učiteljski fakultet, Sveučilište u Zagrebu, Hrvatska \\ e-mail: lana.jurcec@ufzg.hr
}

\begin{abstract}
SAŽETAK Rad se bavi analizom strukture učitelja matematike u osnovnoj školi prema završenom studiju u Hrvatskoj, kao i upotrebom udžbenika u nastavi matematike od strane različitih učitelja matematike (VŠS i VSS). Cilj prikazanoga istraživanja bio je analizirati razlike u korištenju udžbenika između učitelja matematike sa završenom pedagoškom akademijom, učitelja matematike sa završenim nastavničkim sveučilišnim studijem (prof. matematike), te učitelja razredne nastave $s$ pojačanim predmetom matematika. Rezultati pokazuju da se učitelji matematike sa završenom pedagoškom akademijom više oslanjaju na udžbenik i druge materijale ("slijepo korištenje udžbenika"), ali da istovremeno češće prakticiraju individualizirani način rada, prilagođen potrebama učenika. Ovi nalazi su povezani i s radnim iskustvom učitelja u nastavi (Domović i sur., 2012.). Rezultati također pokazuju da učitelji sa završenom pedagoškom akademijom češće prakticiraju individualizirani način rada, prilagođen potrebama učenika. Ispitanici sa završenim sveučilišnim studijem, dakle oni koji su stekli akademski naziv profesora matematike, veliku pažnju poklanjaju matematičkoj točnosti u udžbeničkim sadržajima. Ovi nalazi se mogu povezati sa zahtjevima koji su imali važnu ulogu tijekom njihovoga inicijalnog obrazovanja.
\end{abstract}

Ključne riječi: nastava matematike, učitelj matematike, udžbenik, osnovna škola, nesveučilišni učiteljski studiji, sveučilišni matematički studij. 


\section{Uvod}

Kvalifikacijska struktura predmetnih nastavnika matematike u hrvatskim osnovnim školama s obzirom na završeni studij i stečenu stručnu spremu vrlo je raznolika. Prema Zakonu o odgoju i obrazovanju u osnovnoj i srednjoj školi (NN 87/08), predmetnu nastavu u osnovnoj školi obavljaju "učitelji predmetne nastave" (Članak 1001). Stoga se kadrovi koji poučavaju matematiku u osnovnoj školi nazivaju učiteljima matematike. Na radnom mjestu učitelja matematike ${ }^{1}$ u osnovnoj školi rade stručnjaci koji su završili sveučilišni studij matematike, tj. diplomiranjem stekli titulu profesora matematike ili diplomiranoga inženjera matematike s položenom pedagoškom skupinom predmeta ili u novije vrijeme magistra edukacije matematike. Zatim oni koji su završili studij na jednoj od bivših pedagoških akademija ili visokih učiteljskih škola, te diplomiranjem stekli titulu učitelja matematike ili učitelja razredne nastave s pojačanim predmetom matematika. Nadalje, kao učitelji matematike u osnovnim školama rade i osobe koje su diplomirale na nekom drugom fakultetu, te oni $s$ nezavršenim studijem, uključujući i apsolvente. S obzirom da se programi i duljine studiranja za sve navedene profile bitno razlikuju, moguće je postaviti pitanje o povezanosti razlika u stečenom inicijalnom obrazovanju na samo izvođenje nastave matematike, načine poučavanja, pripremu za nastavu, korištenje udžbenika u nastavi matematike i sl.

\subsection{Broj učitelja matematike}

Prema raspoloživim podacima, u školskoj godini 2008./2009. bilo je zaposleno 2.126 osoba na mjestu učitelja matematike ${ }^{2}$, a u školskoj godini 2009./2010. na mjestu učitelja matematike radilo je 2.085 osoba $^{3}$. Analiza kadrovske strukture učitelja matematike iz 2001. godine pokazuje da je tada 2.173 osobe radilo na radnom mjestu učitelja matematike (Marušić, 2002.). Usporedba gore navedenih podataka svjedoči o trendu smanjivanja broja učitelja matematike u hrvatskim osnovnim školama. S druge strane, podaci Državnoga zavoda za statistiku (DZS) pokazuju rast ukupnoga broja učitelja zaposlenih u osnovnim školama u posljednjih 5 godina, dok se ukupan broj učenika smanjuje (tablica 1.). Podaci o broju učitelja matematike po školskim godinama nisu dostupni u Državnom zavodu za statistiku.

\footnotetext{
1 U dijelovima teksta u kojima se žele naglasiti razlike između radnoga mjesta "učitelj matematike" i titule stečene na bivšim pedagoškim akademijama, koristit će se naziv "učitelj matematike sa završenom pedagoškom akademijom" ili "učitelj matematike (VŠs)".

2 Izvor podatka: Hrvatsko matematičko društvo, studeni 2009.

3 Izvor podatka: Ministarstvo znanosti, obrazovanja i športa, prosinac 2009.
} 
Tablica 1.

Broj učenika i učitelja u osnovnim školama od 2004. do 2009. godine

\begin{tabular}{|c|c|c|c|}
\hline Školska godina & $\begin{array}{c}\text { Broj svih učenika u } \\
\text { osnovnim školama }\end{array}$ & Broj svih učitelja & $\begin{array}{c}\text { Udio žena u profesiji } \\
\text { učitelja }\end{array}$ \\
\hline $\mathbf{2 0 0 4 . / 2 0 0 5 .}$ & 391112 & 28836 & $78,4 \%$ \\
\hline $\mathbf{2 0 0 5 . / 2 0 0 6 .}$ & 386895 & 29256 & $78,9 \%$ \\
\hline $\mathbf{2 0 0 6 . / 2 0 0 7 .}$ & 380777 & 29743 & $79,5 \%$ \\
\hline $\mathbf{2 0 0 7 . / 2 0 0 8 .}$ & 375398 & 30310 & $80,4 \%$ \\
\hline $\mathbf{2 0 0 8 . / 2 0 0 9 .}$ & 369409 & 30908 & $80,8 \%$ \\
\hline
\end{tabular}

Izvor: DZS, 2012.

\subsection{Udio žena u profesiji učitelja matematike}

Iz tablice 1. vidljivo je da je udio žena u ukupnoj profesiji učitelja u osnovnim školama u Hrvatskoj oko 80\%. Prema podacima dobivenim od Ministarstva znanosti obrazovanja i športa, u školskoj godini 2009./2010. ukupan broj zaposlenika na mjestu učitelja matematike bio je 2.085, od čega su 1.634 žene. Podaci govore da je u školskoj godini 2009./2010. udio žena u ukupnom broju učitelja matematike 78,4\%.

\subsection{Stručna sprema i godine staža nastavnika matematike}

Naslov magistra edukacije matematike, odnosno ranije profesora matematike u Republici Hrvatskoj diplomom stječu apsolventi s uspješno završenim sveučilišnim nastavničkim studijem matematike jednoga od sveučilišta u Zagrebu, Osijeku, Rijeci i Splitu ${ }^{4}$. Pritom nastavnički studij može biti i dvopredmetan (matematika i informatika, te matematika i fizika). Ovaj studij podrazumijeva pripremu za izvođenje nastave matematike kako u osnovnoj, tako i u srednjoj školi. Današnji studij za magistra matematičke edukacije traje 10 semestara, a do uvođenja reforme visokoškolskoga obrazovanja (2005. godine) studij za profesora matematike trajao je 8 semestara 5 .

Do 1980. godine učitelji matematike u višim razredima osnovne škole školovali su se na pedagoškim akademijama, odnosno ranije višim pedagoškim školama. U vremenskom periodu od 1951. do 1961. njihov je studij bio trogodišnji i višepredmetan, te je postojala mogućnost stjecanja naziva učitelja iz matematike i fizike, zatim

${ }^{4} \mathrm{~S}$ obzirom da su trenutno magistri edukacije matematike tek novost na tržištu rada, u ovom radu ćemo sve osobe sa završenim sveučilišnim nastavničkim studijem matematike zvati "profesor matematike", odnosno s obzirom da se radi o zaposlenicima u osnovnoj školi "učitelj matematike sa završenim sveučilišnim studijem".

5 Na web stranicama sveučilišta u Zagrebu, Osijeku, Rijeci i Splitu nalaze se poveznice na programe i nazive kolegija nastavničkih studija matematike. 
kemije, fizike i matematike, te crtanja, matematike i hrvatskoga jezika (Puževski, 2005.). Od 1961. studij za predmetne učitelje postaje dvogodišnji i dvopredmetan sa završnom titulom učitelja matematike i fizike (Težak i Markovac, 1971.). Godine 1976., donošenjem reformskih dokumenata, ukidaju se studiji predmetne nastave na pedagoškim akademijama, i ti se studiji od tada počinju provoditi na odgovarajućim nastavničkim fakultetima (Puževski, 2005.). U slučaju učitelja matematike radi se o početku osposobljavanja na nastavničkim studijima u okviru matematičkih fakulteta. Sredinom devedesetih godina prošloga stoljeća u sklopu visokih učiteljskih škola u Hrvatskoj je (nasljednice pedagoških akademija) uveden studij za diplomirane učitelje razredne nastave s pojačanim predmetom matematika. Taj je diplomski studij trajao 8 semestara i bio je organiziran za svega nekoliko generacija studenata.

Posljednja dostupna analiza kadrovske strukture učitelja matematike s obzirom na stručnu spremu napravljena je 2002. godine (Marušić, 2002.). Analiza je pokazala da je 2001. godine u osnovnim školama 61,4\% svih zaposlenih na mjestu učitelja matematike imao završenu pedagošku akademiju. "Takva zastupljenost nastavnika sa završenom pedagoškom akademijom u osnounim školama karakteristična je za sve regije, s time da je njibov udio najmanji u gradu Zagrebu" (Marušić, 2002.:289). Iste godine u osnovnim školama radilo je samo $25 \%$ učitelja sa završenim studijem matematike, tj. titulom profesora matematike, a čak 13\% sa završenim nekim drugim fakultetom ili sa srednjom stručnom spremom, uključujući apsolvente (Marušić, 2002.:290).

S obzirom da je na pedagoškim akademijama 1980. godine prestao studij za predmetne učitelje, obrazovanje budućih predmetnih nastavnika matematike od tada se odvija isključivo na fakultetima, odnosno na sveučilišnim studijima čijim završavanjem se stječe naziv profesor matematike. To znači da se po odlasku u mirovinu, učitelji sa završenim pedagoškim akademijama, zamjenjuju s diplomandima sveučilišnih studija, koji su stekli titulu profesora matematike. Nadalje, to znači da je vrsta završenoga obrazovanja zaposlenika osnovnih škola koji danas rade kao učitelji matematike u direktnoj vezi s dobi i godinama staža učitelja. Učitelji sa završenom bivšom pedagoškom akademijom imaju 30 i više godina staža, dok učitelji s manje staža pretežno dolaze sa sveučilišnih studija. Marušić analizirajući stanje i godine staža u 2001. godini piše: "Dok su nastavnici u srednjim školama ravnomjerno raspoređeni po dobnim skupinama, u osnovnim školama prevladavaju stariji nastavnici. Čak je njih 1.035 (47,6\%) starije od 50 godina. Usporedbom dobne strukture i stručne spreme [...] vidi se da nastavnici u osnovnim školama stariji od 50 godina čine glavninu nastavnika sa završenom pedagoškom akademijom" (Marušić, 2002.:289).

U školskoj godini 2009./10. na mjestu učitelja matematike ${ }^{6}$ radi 2.085 osoba, od čega 46,2\% učitelja matematike sa završenom pedagoškom akademijom, 50,4\% s visokom stručnom spremom (profesori matematike i učitelji s pojačanim predmetom matematika) te 3,4\% nestručnog kadra, uključujući apsolvente. Usporedimo li ove

6 Izvor: Ministarstvo znanosti, obrazovanja i športa, prosinac 2009. 
podatke s podacima iz 2001. godine, primijetit ćemo pad broja zaposlenih učitelja matematike sa završenom pedagoškom akademijom zbog odlaska u mirovinu. Na ta radna mjesta zaposlen je novi stručni kadar, a to su profesori matematike čiji je postotak udvostručen u ovih 8 godina. Važno je napomenuti i činjenicu da je od 1996. znatno uvećan broj diplomiranih profesora matematike na sveučilišnim studijima u Hrvatskoj (Marušić, 2002.:292).

\subsection{Eksperimentalno vanjsko vrednovanje obrazovnih postignuća u osnovnim školama u Republici Hrvatskoj}

S obzirom na spomenute razlike u obrazovanju, odnosno vrsti institucija (sveučilišne institucije i visoke škole) na kojima su se školovale osobe koje rade na radnom mjestu učitelja matematike u osnovnim školama u Hrvatskoj, moguće je zapitati jesu li te razlike povezane s nastavnom praksom i s učeničkim postignućima iz matematike. U školskoj godini 2006./07. provedeno je Eksperimentalno vanjsko vrednovanje obrazovnih postignuća u osnovnim školama u Republici Hrvatskoj iz hrvatskog jezika i matematike (Institut društvenih znanosti Ivo Pilar, 2007.). Rezultati pokazuju da su učenici koje su poučavale žene u prosjeku postigli bolje rezultate od onih učenika koje su poučavali muškarci (Institut društvenih znanosti Ivo Pilar, 2007.:88). Jedno od mogućih objašnjenja ovoga nalaza je i način rada koji prakticiraju učitelji, odnosno učiteljice. Ispitujući upotrebu udžbenika u nastavi matematike s obzirom na spol i staž učitelja, Domović, Glasnović Gracin i Jurčec (2012.) utvrdile su da ne postoje statistički značajne razlike u upotrebi udžbenika kod učiteljica i učitelja matematike u osnovnoj školi, osim pri upoznavanju s novim sadržajima. Naime, muški ispitanici su se značajno više od žena izjasnili da njihovi učenici samostalno usvajaju novo gradivo iz udžbenika.

Objavljeni rezultati nacionalnih ispita (Institut društvenih znanosti Ivo Pilar, 2007.) također pokazuju da stručno zastupljena nastava i još neka obilježja nastavnika matematike utječu na uspjeh učenika u ovom ispitivanju. "S druge strane, obilježja učitelja $i$ nastave značajnije $i$ izraženije su povezana s izmjerenim postignućima učenika. Škole koje imaju u cijelosti stručno zastupljenu nastavu, u kojima postoji veci broj stručnih suradnika, u kojima se tijekom obrazovnoga ciklusa nisu mijenjali predmetni učitelji te koje izvode nastavu u specijaliziranim učionicama jesu škole iz kojih dolaze učenici koji postižu bolje rezultate na ispitima iz hrvatskog jezika $i$ matematike" (Institut društvenih znanosti Ivo Pilar, 2007.:8). Na koji način nastava matematike koju realiziraju osobe koje nemaju propisanu stručnu spremu utječe na uspjeh učenika iz matematike može se vidjeti iz rezultata "...da relativno najslabiji uspjeh postižu učenici koje su poučavali učitelji koji nemaju formalno propisanu stručnu spremu za obavljanje poslova učitelja brvatskog jezika i matematike" (Institut društvenih znanosti Ivo Pilar, 2007.:86). Također je zanimljivo da "...su najuspješniji učenici koje su poučavali učitelji/učiteljice brvatskog jezika sa stručnom spremom VSS profesor hrvatskog jezika, a u slučaju matematike VŠS učitelj/učiteljica matematike" (Institut društvenih znanosti Ivo Pilar, 2007.:8). 
Rezultati nacionalnih ispita s obzirom na staž pokazuju da učitelji s 30 do 40 godina staža imaju učenike s najboljim rezultatima, no zanimljiv je očit pad uspjeha učenika kod nastavnika od preko 40 godina staža: "u slučaju rezultata na ispitu iz matematike dolazi do pada uspješnosti učenika koje su poučavali učitelji koji imaju više od 40 godina radnog staža"(Institut društvenih znanosti Ivo Pilar, 2007.:9).

\subsection{Upotreba matematičkih udžbenika u nastavi viših razreda osnovne škole}

Iz gore navedenih rezultata vidljivo je da su u hrvatskim osnovnim školama kao učitelji matematike zaposleni kadrovi koji se značajno razlikuju s obzirom na vrstu završenog studija i stupanj stručne spreme. Stoga je važno utvrditi postoje li i razlike u načinima poučavanja, pripremi za nastavni sat, metodičkim postupcima, diferencijaciji nastavnoga sata i sl., s obzirom na spomenute razlike u obrazovanju učitelja matematike.

Jedan od pokazatelja načina rada učitelja je korištenje udžbenika u različitim etapama nastavnoga procesa zbog njegovoga velikog utjecaja na poučavanje i učenje u školama. Istraživanje o upotrebi matematičkih udžbenika u osnovnim školama u Republici Hrvatskoj provedeno je 2008. godine (Glasnović Gracin i Domović, 2009.). Ciljevi istraživanja bili su višestruki. Jedan od ciljeva bio je utvrditi u kojoj mjeri i na koji način se matematički udžbenik koristi u nastavi viših razreda osnovne škole, te koji načini poučavanja dominiraju u nastavi prilikom korištenja udžbenika u višim razredima osnovne škole. Prikupljeni podaci pokazali su da matematički udžbenici imaju važnu ulogu u nastavi matematike viših razreda osnovne škole u Hrvatskoj, što je sukladno nalazima istraživanja u drugim zemljama (npr. Robitaille i Garden, 1989.; Schmidt i sur., 1996.; Pepin i Haggarty, 2001.). Matematički udžbenici koriste se posebice prilikom pripreme nastavnika za nastavu i prilikom vježbanja učenika, te za domaće zadaće. Nadalje, veliki utjecaj udžbenika očituje se i u tome da učitelji slijede strukturu i redoslijed pojedinih tema u udžbeniku, u velikom broju koriste metodičke postupke opisane u udžbeniku, te upotrebljavaju jezik i matematičke simbole koji se koriste u udžbeniku. Također je utvrđeno da se novi sadržaji učenicima uglavnom prezentiraju frontalnim radom kod kojega učenici pasivno slušaju izlaganje nastavnika, a tek potom slijedi učenički angažman kroz rješavanje zadataka iz udžbenika. Budući da se nastavnici u vrlo velikom broju pripremaju po udžbeniku, njihovu ulogu prilikom objašnjavanja novoga gradiva možemo shvatiti kao posredničku između udžbeničkoga teksta i učenika (Glasnović Gracin i Domović, 2009.). Nadalje, rezultati su pokazali da ne postoje statistički značajne razlike u korištenju udžbenika s obzirom na spol učitelja matematike, dok duljina radnoga iskustva učitelja značajno utječe na način upotrebe udžbenika u nastavi (Domović i sur., 2012.). Učitelji matematike s radnim stažem duljim od 30 godina značajno više koriste udžbenik, druge izvore poučavanja, te njihova nastava najviše ide u susret različitim potrebama učenika. S obzirom da je duljina radnoga iskustva u izravnoj vezi s vrstom obrazovanja učitelja matematike, zanimljivo je istražiti koriste li učitelji, koji su imali različito inicijalno obrazovanje, udžbenike na različit način u nastavnom procesu. 


\section{Cilj i metodologija istraživanja}

\subsection{Cilj istraživanja}

Cilj ovoga istraživanja bio je utvrditi postoje li razlike u uporabi i odabiru udžbenika s obzirom na vrstu inicijalnoga obrazovanja učitelja matematike.

\subsection{Uzorak}

Istraživanje je provedeno u razdoblju od travnja do srpnja 2008. godine na Županijskim stručnim vijećima za matematiku u osnovnoj školi. Prema dostupnim podacima, među prisutnim sudionicima Županijskih stručnih vijeća, nije bilo sudionika koji su odbili ispuniti anketu. Anketu je valjano popunilo 987 učitelja/učiteljica matematike viših razreda osnovne škole u Republici Hrvatskoj, što prema dostupnim podacima ${ }^{7}$, te drugim izvorima (Marušić, 2002.) čini oko 45\% ukupnoga broja nastavnika matematike iz osnovnih škola na teritoriju Republike Hrvatske. Udio žena u ukupnom broju ispitanika iznosio je 80\%. Navedeni podatak poklapa se kako s udjelom žena u profesiji učitelja uopće, tako is podacima o udjelu žena u profesiji učitelja matematike.

Iz tablice 2. (244 str.) vidljiva je struktura ispitanika prema duljini radnoga staža i inicijalnoga obrazovanja. Prema duljini radnoga staža bilo je 14\% učitelja matematike sa stažem u školi manjim od 5 godina, 23\% ispitanika sa stažem između 6 do 15 godina, 25\% učitelja između 16 i 30 godina radnoga staža, a 39\% ispitanika je imalo više od 30 godina radnoga staža. S obzirom na stručnu spremu, odnosno vrstu završenoga obrazovanja, 38\% ispitanika završilo je sveučilišni studij matematike, te su na taj način stekli akademsku titulu profesora matematike, 51\% ispitanika su činili ispitanici s titulom učitelja matematike (završena pedagoška akademija prema programima do 1980.), a 11\% uzorka činili su učitelji razredne nastave s pojačanim predmetom matematika. U originalnom istraživanju bila je mogućnost odabrati i nestručno zastupljen kadar, no za ovu analizu ti ispitanici nisu uzimani u obzir.

S obzirom da se u dostupnim podacima Ministarstva znanosti, obrazovanja i športa radi samo podjela na srednju, visoku i višu stručnu spremu, na žalost, nemamo podataka o udjelu učitelja razredne nastave s pojačanom matematikom i inženjera matematike u sveukupnoj populaciji učitelja matematike. U podacima Ministarstva navodi se podatak da u osnovnim školama na mjestu učitelja matematike radi 3,4\% osoba sa završenom srednjom stručnom spremom, ali u ovom istraživanju nije prikupljen podatak o udjelu takvih osoba, već o nestručnima, uključujući apsolvente. No, ukupno gledajući, moguće je zaključiti da se distribucija ispitanika u istraživanju s obzirom na stručnu spremu slaže s podacima u populaciji učitelja matematike u osnovnim školama (slika 1./244 str.).

${ }^{7}$ Izvori: Ministarstvo znanosti, obrazovanja i športa, prosinac 2009. i Hrvatsko matematičko društvo, studeni 2009. 
Tablica 2.

Kontingencijska tablica inicijalnoga obrazovanja i godina radnoga staža

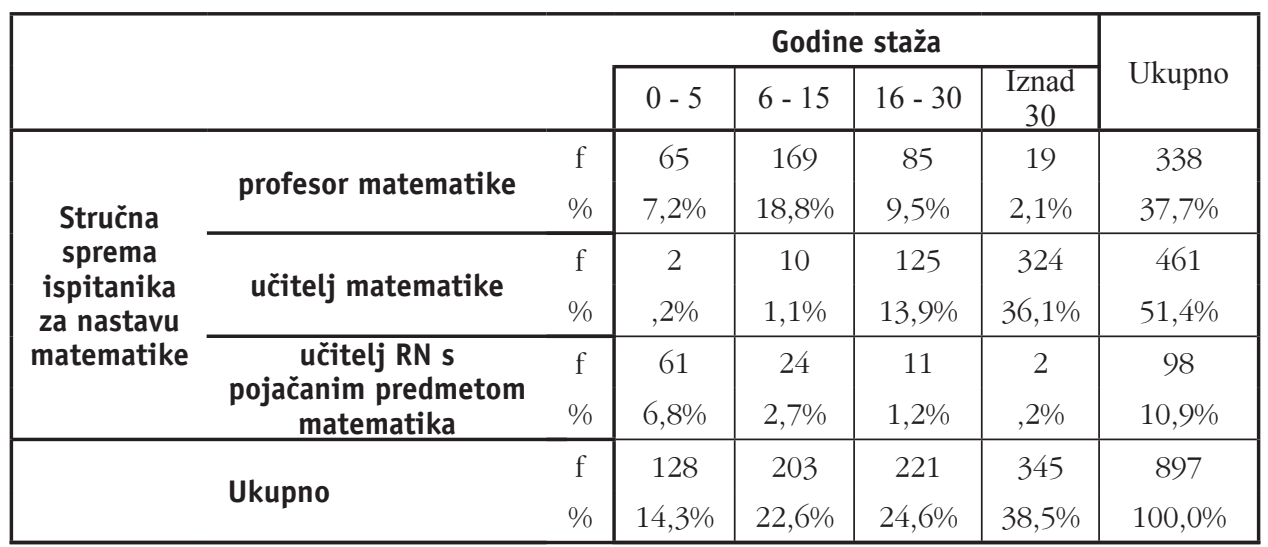

Pearsonov hi²=681,331 uz p <0,01; kontingencijski koeficijent 0,657 uz $\mathrm{p}<0,01$

Slika 1.

Usporedba raspodjele s obzirom na stručnu spremu u uzorku istraživanja i u ukupnoj populaciji učitelja matematike

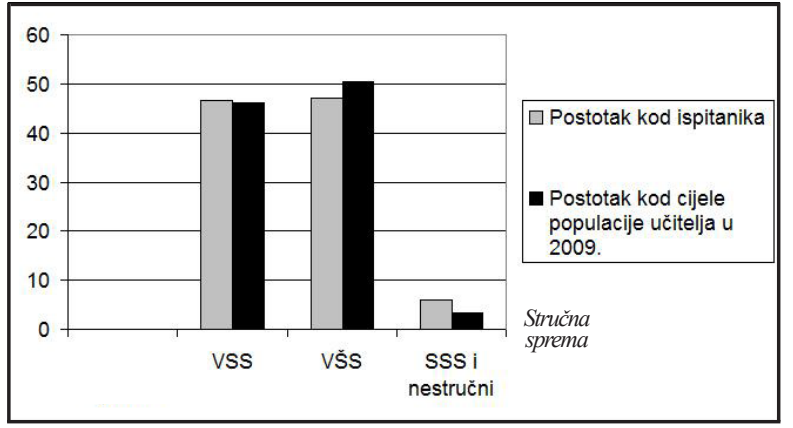

\subsection{Instrument i postupak istraživanja}

Upitnik za učitelje: uloga matematičkih udžbenika u nastavi osnovne škole konstruiran je za potrebe širega istraživanja udžbeničkoga sadržaja ${ }^{8}$ (Glasnović Gracin, 2011.; Glasnović Gracin i Domović, 2009.), a za potrebe ovoga članka koristio se samo dio navedenoga upitnika. Anketiranje je provedeno na Županijskim vijećima iz matematike u osnovnim školama u periodu od travnja do srpnja 2008. godine?

8 Udžbenik u ovom tekstu podrazumijeva cijeli propisani udžbenički komplet (uključujući zbirku zadataka i ostale obavezne materijale). Materijali koji nisu dio obveznoga kompleta u ovom tekstu se ne smatraju udžbenikom.

9 Primjenu upitnika na Županijskim stručnim vijećima učitelja matematike odobrila je Agencija za odgoj i obrazovanje (Kl: 602-02/07-01/0186, Ur. broj: 561-01/2-07-1). 
Tvrdnje u upitniku sastavljene su na temelju analize ciljeva o uporabi udžbenika, te pregleda relevantne literature (primjerice, Pepin i Haggarty, 2001.). Prvi dio upitnika odnosio se na demografske podatke o ispitanicima (5 tvrdnji). Slijede 24 tvrdnje vezane uz upotrebu udžbenika u nastavi matematike. U njima je percepcija učitelja matematike mjerena procjenjivanjem svake pojedine tvrdnje na modificiranoj Likertovoj skali od 4 stupnja ("nikad" /stupanj 1/, "rijetko" /stupanj 2/, "često" /stupanj 3/, te "gotovo uvijek" /stupanj 4/). Također, istraživanje je obuhvatilo jedno pitanje o kriterijima prilikom odabira udžbenika. Pitanje je podrazumijevalo izbor između unaprijed ponuđenih odgovora s mogućnošću odabira do tri odgovora.

Valjanost ${ }^{10}$ primijenjenog Upitnika za učitelje: uloga matematičkih udžbenika u nastavi osnovne škole, provjerena je faktorskom analizom, metodom glavnih komponenata (PCA) sa Varimax rotacijom. Ekstrahirana su četiri faktora koji zadovoljavaju Guttman-Kaiserov kriterij. Navedena četiri faktora zajedno objašnjavaju 43,4\% varijance korištenja udžbenika u nastavi matematike. Prvi faktor odnosi se na utjecaj sadržaja i strukture udžbenika, kako za pripremu tako i za način organiziranja i izvođenja nastavnoga sata (npr. metodičke postupke, matematički jezik i sl.), stoga je nazvan "Slijepo" korištenje udžbenika u nastavi matematike. Drugi faktor se odnosi na udžbenički komplet kao izvor matematičkih zadataka za vježbu i ponavljanje u nastavi matematike, stoga je nazvan Orijentacija na rješavanje zadataka iz udžbenika. Treći ekstrahirani faktor, nazvan Korištenje drugih izvora poučavanja, sadržajno se odnosi na spremnost nastavnika za pronalaženjem i korištenjem dodatnih izvora za pripremu nastave matematike mimo odabranoga obaveznog udžbenika. Četvrti ekstrahirani faktor (Individualizirani pristup u nastavi) odnosi se na orijentaciju na različite potrebe i mogućnosti učenika u nastavi matematike, kao i na individualizirani pristup u korištenju udžbenika u nastavi matematike osnovne škole. Sadržaj tvrdnji koje su visoko povezane s ovim faktorom ukazuje na negativnu povezanost individualiziranoga pristupa i frontalne nastave. Pouzdanosti prvih triju faktora su zadovoljavajuce (0,69 za II. i III., te 0,82 za I. faktor), međutim Cronbachov alfa koeficijent IV. faktora ukazuje na relativno nisku pouzdanost $(\alpha=0,57)$, što nalaže oprezniju interpretaciju rezultata.

\section{Rezultati istraživanja i diskusija}

\subsection{Upotreba udžbenika s obzirom na inicijalno obrazovanje ispitanika}

S obzirom da su učenici čiji učitelji imaju višu stručnu spremu imali bolje rezultate na nacionalnom ispitu iz matematike 2007. godine od učenika čiji učitelji imaju visoku stručnu spremu, postavlja se pitanje postoje li razlike u načinu rada tih grupa učitelja u nastavnom procesu. Jedan od mogućih pokazatelja načina rada je i pristup upotrebi udžbenika. Budući da se trajanje studija, kao i studijski programi, razlikuju

10 Detaljnije o metrijskim karakteristikama instrumenta vidjeti u: Domović, Glasnović Gracin i Jurčec (2012.) 
za učitelje matematike sa završenim sveučilišnim i nesveučilišnim studijima, zanimljivo je ispitati postoje li razlike u upotrebi udžbenika između ovih dvaju profila. Također, u tom kontekstu važno je vidjeti i kako udžbenik koriste učitelji razredne nastave s pojačanim predmetom matematika, tj. u kojoj mjeri se razlikuju ili ne razlikuju od svojih kolega s matematičkih studija i pedagoških akademija.

Budući da su ispitanici označavali kategoriju staža kojoj pripadaju, a u pojedinim kategorijama staža i inicijalnoga obrazovanja nema dovoljnoga broja ispitanika, ugrožena je provedba primjerenih statističkih analiza ${ }^{11}$ kojima bi se kontrolirao ili provjeravao utjecaj zavisnoga odnosa staža i inicijalnoga obrazovanja (tablica 2.). Iz navedenih razloga, za provjeru statističke značajnosti razlika provedene su jednosmjerne analize varijance, a u samoj interpretaciji rezultata vodilo se računa o zavisnom odnosu staža i titule nastavnika matematike u korištenju matematičkih udžbenika.

Rezultati ovoga istraživanja pokazuju da ispitanici, bez obzira na svoje inicijalno obrazovanje, matematički udžbenik najviše koriste kao izvor zadataka za vježbu i domaću zadaću (Faktor II). No, utvrđene su statistički značajne razlike (tablica 3.) u korištenju udžbenika između učitelja matematike sa završenom bivšom pedagoškom akademijom (titula "učitelj matematike") i onih sa završenim sveučilišnim matematičkim studijem (titula "prof. matematike") u faktorima I i IV ( "Slijepo" korištenje udžbenika, te Individualizirani pristup u nastavi).

Tablica 3.

Deskriptivni pokazatelji i testiranje značajnosti razlika u korištenju udžbenika s obzirom na titulu nastavnika matematike

\begin{tabular}{|c|c|c|c|c|c|c|}
\hline & titula & N & M & SD & $\mathbf{F}$ & $\mathrm{p}$ \\
\hline \multirow{3}{*}{$\begin{array}{c}\text { Faktor I: “Slijepo" } \\
\text { korištenje udžbenika }\end{array}$} & profesor matematike & 329 & $3,05_{2}$ & 0,38 & \multirow{3}{*}{6,248} & \multirow{3}{*}{0,002} \\
\hline & učitelj matematike & 436 & $3,14_{1}$ & 0,35 & & \\
\hline & $\begin{array}{l}\text { učitelj RN s pojačanim } \\
\text { predmetom matematika }\end{array}$ & 96 & 3,07 & 0,34 & & \\
\hline \multirow{3}{*}{$\begin{array}{c}\text { Faktor II: Orijentacija } \\
\text { na rješavanje zadataka } \\
\text { iz udžbenika }\end{array}$} & profesor matematike & 337 & 3,49 & 0,43 & \multirow{3}{*}{0,287} & \multirow{3}{*}{0,750} \\
\hline & učitelj matematike & 457 & 3,50 & 0,40 & & \\
\hline & $\begin{array}{l}\text { učitelj RN s pojačanim } \\
\text { predmetom matematika }\end{array}$ & 96 & 3,52 & 0,39 & & \\
\hline
\end{tabular}

11 Prema Tabachnick i Fidell (2007.) osnovni kriterij za odabir kovarijata u analizi kovarijance je kontinuirana varijabla koju se nastoji kontrolirati. Za dvosmjernu analizu varijance potrebna je dovoljna zastupljenost ispitanika u svim kategorijama staž x inicijalno obrazovanje (akademska titula). 


\begin{tabular}{|c|c|c|c|c|c|c|}
\hline & titula & $\mathrm{N}$ & M & SD & $\mathbf{F}$ & $\mathrm{p}$ \\
\hline \multirow{3}{*}{$\begin{array}{l}\text { Faktor III: Korištenje } \\
\text { drugih izvora } \\
\text { poučavanja }\end{array}$} & profesor matematike & 333 & 2,65 & 0,42 & \multirow{3}{*}{0,990} & \multirow{3}{*}{0,372} \\
\hline & učitelj matematike & 450 & 2,69 & 0,43 & & \\
\hline & $\begin{array}{l}\text { učitelj RN s pojačanim } \\
\text { predmetom matematika }\end{array}$ & 98 & 2,64 & 0,44 & & \\
\hline \multirow{3}{*}{$\begin{array}{c}\text { Faktor IV: } \\
\text { Individualizirani } \\
\text { pristup u korištenju } \\
\text { udžbenika }\end{array}$} & profesor matematike & 337 & $2,35_{2}$ & 0,42 & \multirow{3}{*}{46,345} & \multirow{3}{*}{0,000} \\
\hline & učitelj matematike & 456 & $2,59_{1,3}$ & 0,38 & & \\
\hline & $\begin{array}{l}\text { učitelj RN s pojačanim } \\
\text { predmetom matematika }\end{array}$ & 97 & $2,29_{2}$ & 0,37 & & \\
\hline
\end{tabular}

Napomena: Brojevi pored prosjeka označavaju usporedbe prema Tukeyovom HSD post hoc testu značajnosti razlika u rezultatima s obzirom na tri kategorije obrazovanja.

Rezultati pokazuju da se učitelji sa stručnom spremom "učitelj matematike" više oslanjaju na udžbenik u odnosu na svoje kolege koji su stekli akademski naziv "profesor matematike" (npr. prilikom pripreme za nastavu, te češće slijede strukturu i sadržaje iz udžbenika u nastavi). Iako je dobivena navedena razlika statistički značajna, veličina njenoga utjecaja na "Slijepo korištenje udžbenika" je zapravo mala $\left(\mathrm{eta}^{2}=0,014\right)$. U prvom faktoru ističu se statistički značajne razlike u izjavama prikazanima u tablici 4. Izjave o velikom oslanjanju na metodički priručnik s jedne strane mogu ukazivati na intenzivno korištenje gotovih priprema koje se nalaze u priručniku, a s druge strane mogu ukazivati na zanimanje za ostale metodičke teme i naputke iz priručnika. Nalaz od Domović i sur. (2012.) pokazuje da se učitelji iznad 30 godina staža značajno više koriste udžbenikom od svojih mlađih kolega, pa jedan od razloga za veliko korištenje udžbenika može biti i iskustvo tj. "bolji uvid u zadatke na kojima se treba dulje zadržati, a što je moguće preskočiti, koje metode su efikasnije $i$ sl." (ibid.: 198). Također, nalaz pokazuje da ispitani učitelji sa završenom pedagoškom akademijom u većoj mjeri učenicima obraćaju pažnju na crteže i slike iz udžbenika, što može ukazivati na veći senzibilitet prema pristupu uvođenja i objašnjavanja matematičkih pojmova, te u komunikaciji s učenicima (tablica 4.). S druge strane, učitelji sa završenom pedagoškom akademijom u većoj mjeri slijepo slijede udžbeničku strukturu na nastavnom satu, koriste iste simbole i jezik kao iz udžbenika, te ističu dijelove gradiva koji su istaknuti u udžbeniku. Učitelji s titulom profesora matematike u značajnoj se manjoj mjeri obaziru na to. Ovaj nalaz može ukazivati na činjenicu da obrazovanje na matematičkim fakultetima nastavnicima daje određenu sigurnost i fleksibilnost da u nastavi koriste i druge dopuštene simbole i jezik, nego što je to prikazano u odabranom udžbeniku, dok učitelji sa završenom pedagoškom akademijom radije koriste simbole i jezik iz udžbenika. Na taj način udžbeniku se daje veći autoritet, ali se i učenicima olakšava služenje udžbeničkim kompletom jer se ne stvaraju zabune. Dodatna istraživanja (npr. intervjui, opservacije nastave i sl.) pomogla bi u interpretaciji ovih rezultata, posebice stoga što svakako treba uzeti u obzir mogućnost davanja socijalno poželjnih odgovora kod ispitanika. 
Tablica 4.

Deskriptivni pokazatelji i testiranje značajnosti razlika u tvrdnjama o slijepom slijeđenju udžbenika s obzirom na titulu nastavnika matematike

\begin{tabular}{|c|c|c|c|c|c|c|}
\hline & & $\mathbf{N}$ & M & SD & $\mathbf{F}$ & $\mathrm{p}$ \\
\hline \multirow{3}{*}{$\begin{array}{l}\text { 6.2. Prilikom pripreme } \\
\text { za nastavu oslanjam se } \\
\text { na pripadni priručnik za } \\
\text { nastavnike. }\end{array}$} & profesor matematike & 337 & $2,91_{2}$ & 0,76 & \multirow{3}{*}{4,592} & \multirow{3}{*}{0,010} \\
\hline & učitelj matematike & 453 & $3,06_{1}$ & 0,67 & & \\
\hline & $\begin{array}{l}\text { učitelj RN s pojačanim } \\
\text { predmetom matematika }\end{array}$ & 98 & 2,93 & 0,74 & & \\
\hline \multirow{3}{*}{$\begin{array}{l}\text { 7.1. Na svom nastavnom } \\
\text { satu točno slijedim strukturu } \\
\text { pojedine lekcije iz udžbenika. }\end{array}$} & profesor matematike & 338 & $2,96_{2}$ & 0,64 & \multirow[t]{3}{*}{4,629} & \multirow[t]{3}{*}{0,010} \\
\hline & učitelj matematike & 460 & $3,09_{1}$ & 0,65 & & \\
\hline & $\begin{array}{l}\text { učitelj RN s pojačanim } \\
\text { predmetom matematika }\end{array}$ & 98 & 3,06 & 0,57 & & \\
\hline \multirow{3}{*}{$\begin{array}{l}\text { 8.2. U nastavi koristim } \\
\text { matematički jezik i simbole } \\
\text { koji se koriste u izabranom } \\
\text { udžbeniku. }\end{array}$} & profesor matematike & 338 & $3,56_{2}$ & 0,54 & \multirow[t]{3}{*}{6,876} & \multirow[t]{3}{*}{0,001} \\
\hline & učitelj matematike & 458 & $3,69_{1}$ & 0,48 & & \\
\hline & $\begin{array}{l}\text { učitelj RN s pojačanim } \\
\text { predmetom matematika }\end{array}$ & 98 & 3,64 & 0,48 & & \\
\hline \multirow{3}{*}{$\begin{array}{l}\text { 8.3. Učenicima skrećem } \\
\text { pažnju na ilustracije/ } \\
\text { fotografije/stripove iz } \\
\text { udžbenika. }\end{array}$} & profesor matematike & 338 & $3,13_{2}$ & 0,72 & \multirow[t]{3}{*}{8,017} & \multirow[t]{3}{*}{0,000} \\
\hline & učitelj matematike & 456 & $3,31_{1}$ & 0,62 & & \\
\hline & $\begin{array}{l}\text { učitelj RN s pojačanim } \\
\text { predmetom matematika }\end{array}$ & 98 & 3,15 & 0,68 & & \\
\hline \multirow{3}{*}{$\begin{array}{l}\text { 8.4. U nastavi ističem iste } \\
\text { dijelove gradiva koji su na } \\
\text { poseban način istaknuti u } \\
\text { udžbeniku. }\end{array}$} & profesor matematike & 337 & $3,19_{2}$ & 0,65 & \multirow[t]{3}{*}{4,183} & \multirow[t]{3}{*}{0,016} \\
\hline & učitelj matematike & 454 & $3,32_{1}$ & 0,63 & & \\
\hline & $\begin{array}{l}\text { učitelj RN s pojačanim } \\
\text { predmetom matematika }\end{array}$ & 97 & 3,24 & 0,64 & & \\
\hline \multirow{3}{*}{$\begin{array}{l}\text { 9. Za motivaciju prilikom } \\
\text { uvoda u novu temu ili } \\
\text { lekciju koristim sadržaje iz } \\
\text { udžbenika. }\end{array}$} & profesor matematike & 337 & $2,77_{2}$ & 0,61 & \multirow[t]{3}{*}{7,935} & \multirow[t]{3}{*}{0,000} \\
\hline & učitelj matematike & 459 & $2,90_{1,3}$ & 0,64 & & \\
\hline & $\begin{array}{l}\text { učitelj RN s pojačanim } \\
\text { predmetom matematika }\end{array}$ & 98 & $2,66_{2}$ & 0,70 & & \\
\hline
\end{tabular}

Napomena: Brojevi pored prosjeka označavaju usporedbe prema Tukeyovom HSD post hoc testu značajnosti razlika u rezultatima s obzirom na tri kategorije obrazovanja.

Zanimljive su i razlike kod korištenja udžbenika prilikom motivacije za usvajanje novih nastavnih sadržaja. Rezultati upućuju da ispitanici sa završenom pedagoškom akademijom češće koriste udžbeničke sadržaje kako bi učenike motivirali pri uvodu u nove sadržaje, u odnosu na profesore i diplomirane učitelje s pojačanom matema- 
tikom. Ovaj nalaz ukazuje da njima udžbenik nije samo izvor zadataka za vježbu, već i sredstvo za motiviranje i razonodu s matematičkim motivima. Nadalje, nalaz se može povezati s korištenjem ilustracija i slika iz udžbenika koje ponekad također mogu biti prikladan uvod u određenu temu. Kod ovih rezultata također treba imati na umu bogato radno iskustvo učitelja sa završenom pedagoškom akademijom.

Tablica 5.

Postoci i testiranje značajnosti razlike u kriterijima prilikom odabira udžbenika s obzirom na titulu nastavnika matematike

\begin{tabular}{|l|c|c|c|c|c|c|}
\hline $\begin{array}{l}\text { Koji kriteriji su Vam } \\
\text { najvažniji prilikom } \\
\text { odabira udžbenika? }\end{array}$ & $\begin{array}{c}\text { profesor } \\
\text { matematike }\end{array}$ & $\begin{array}{c}\text { učitelj } \\
\text { matematike }\end{array}$ & $\begin{array}{c}\text { učitelj RN s } \\
\text { pojačanom } \\
\text { matematikom }\end{array}$ & Ukupno & $\chi^{\mathbf{2}}$ & $\mathbf{p}$ \\
\hline $\begin{array}{l}\text { a) odabir primjera i } \\
\text { zadataka }\end{array}$ & $70,20 \%$ & $63,00 \%$ & $63,30 \%$ & $65,70 \%$ & 4,824 & 0,090 \\
\hline $\begin{array}{l}\text { b) primjerenost } \\
\text { sadržaja dobi } \\
\text { učenika }\end{array}$ & $\mathbf{5 9 , 9 0 \%}$ & $63,90 \%$ & $\mathbf{7 3 , 5 0 \%}$ & $63,40 \%$ & $\mathbf{6 , 1 3 1}$ & $\mathbf{0 , 0 4 7}$ \\
\hline $\begin{array}{l}\text { c) matematička } \\
\text { točnost i korektnost }\end{array}$ & $\mathbf{4 6 , 0 0 \%}$ & $\mathbf{2 9 , 9 0 \%}$ & $35,70 \%$ & $36,60 \%$ & $\mathbf{2 2 , 0 0 9}$ & $\mathbf{0 , 0 0 0}$ \\
\hline $\begin{array}{l}\text { d) usklađenost } \\
\text { udžbenika s planom } \\
\text { i programom }\end{array}$ & $\mathbf{3 7 , 2 0 \%}$ & $\mathbf{5 3 , 0 0 \%}$ & $43,90 \%$ & $46,10 \%$ & $\mathbf{2 0 , 0 1 1}$ & $\mathbf{0 , 0 0 0}$ \\
\hline $\begin{array}{l}\text { e) grafičko } \\
\text { oblikovanje }\end{array}$ & $16,20 \%$ & $13,20 \%$ & $13,30 \%$ & $14,30 \%$ & 1,557 & 0,459 \\
\hline $\begin{array}{l}\text { f) metodičko } \\
\text { oblikovanje }\end{array}$ & $47,80 \%$ & $41,80 \%$ & $39,80 \%$ & $43,80 \%$ & 3,597 & 0,166 \\
\hline g) ime autora & $1,50 \%$ & $2,80 \%$ & $1,00 \%$ & $2,10 \%$ & 2,330 & 0,312 \\
\hline $\begin{array}{l}\text { h) beneficije } \\
\text { izdavača }\end{array}$ & $0,60 \%$ & $0,40 \%$ & $1,00 \%$ & $0,60 \%$ &, 516 & 0,773 \\
\hline $\begin{array}{l}\text { i) ne odlučujem ja o } \\
\text { udžbeniku }\end{array}$ & $2,10 \%$ & $0,90 \%$ & $4,10 \%$ & $1,70 \%$ & 5,617 & 0,060 \\
\hline \begin{tabular}{l} 
j) nešto drugo \\
\hline
\end{tabular} & $0 \%$ & $0,60 \%$ & $0 \%$ & $0,30 \%$ & 2,847 & 0,241 \\
\hline
\end{tabular}

Nadalje, tablica 5. prikazuje kriterije koji su pojedinoj skupini učitelja matematike najvažniji prilikom odabira udžbenika ${ }^{12}$. Rezultati pokazuju da su se učitelji matematike sa završenom pedagoškom akademijom u značajno većoj mjeri odlučili za krit-

12 U vrijeme provođenja istraživanja učitelji matematike imali su mogućnost na kraju svake školske godine samostalno odlučiti koji će udžbenik koristiti u narednoj školskoj godini sa svojim razredima. 
erij usklađenosti udžbenika s planom i programom, u odnosu na profesore matematike, dok je profesorima matematike važnija matematička točnost i korektnost u udžbeničkim sadržajima. Navedeni nalazi su u skladu s rezultatima od Domović i sur. (2012.), o kriterijima s obzirom na godine staža. Naime, učitelji s više godina staža prvenstveno su se odlučili za kriterij usklađenosti udžbenika s planom i programom, dok su se njihovi mlađi kolege izjasnili da im je za odabir udžbenika najvažnija matematička točnost i korektnost. Ovi odgovori, uz iskustvo, mogu ukazivati na parametre na koje je bio stavljan naglasak u inicijalnom obrazovanju ovih dviju skupina nastavnika.

Zanimljivo je primijetiti da se statistički značajne razlike uglavnom odnose na prve dvije skupine učitelja (učitelji sa završenim matematičkim studijem i pedagoškom akademijom). Odgovori učitelja razredne nastave $s$ pojačanom matematikom uglavnom se nalaze "negdje između" ove dvije skupine i ne razlikuju se značajno niti od jedne od njih. No, učitelji razredne nastave s pojačanom matematikom u značajno su većem postotku u odnosu na profesore matematike izjavili da im je za odabir udžbenika važna primjerenost sadržaja dobi učenika (tablica 5.).

Četvrti ekstrahirani faktor odnosi se na individualizirani pristup u korištenju udžbenika u nastavi matematike osnovne škole. Rezultati pokazuju da postoji statistički značajna razlika u individualiziranom pristupu u nastavi između profesora matematike, učitelja s pedagoških akademija, te učitelja razredne nastave s pojačanim predmetom matematika (tablica 3.). Veličina te razlike izražena pomoću pokazatelja eta $^{2}$ iznosi 0,095, što prikazuje srednji utjecaj. U svim tvrdnjama četvrtoga faktora pokazala se statistički značajna razlika u odgovorima (tablica 6.). Rezultati pokazuju da ispitani učitelji matematike sa završenom pedagoškom akademijom u statistički značajnijoj mjeri potiču individualizaciju prema sposobnostima učenika u odnosu na ispitane profesore matematike i učitelje razredne nastave s pojačanim predmetom matematika (izjave 10.2, 13 i 14 u tablici 6.). Ovaj nalaz se može protumačiti iskustvom kojega ovi učitelji posjeduju (radi se o učiteljima matematike s preko 30 godina staža), ali i senzibilitetu ove kategorije učitelja matematike prema načelima individualizacije i primjerenosti u nastavi matematike.

Rezultati pokazuju da učitelji razredne nastave s pojačanim predmetom matematika značajno više nove sadržaje poučavaju frontalnim radom u odnosu na kolege $s$ matematičkih studija i pedagoških akademija (tvrdnja 10.1 u tablici 6.). Navedeni nalaz možda se može protumačiti njihovim nedovoljnim iskustvom u slobodnijim odabirima pri obradi novoga gradiva ili nedovoljnom zastupljenošću matematičkih sadržaja tijekom inicijalnoga obrazovanja čijim bi ovladavanjem stekli veću profesionalnu slobodu u donošenju odluka o organizaciji i izvođenju nastave. Nadalje, rezultati pokazuju da učitelji sa završenom pedagoškom akademijom pokazuju veći senzibilitet za didaktičke (nematematičke) zahtjeve u nastavi matematike (pedagoške, komunikacijske, psihološke, metodičke), koji su usmjereni na učenika, dok je njihovim kolegama sa završenim matematičkim studijem važnija točnost matematičkih sadržaja. Učitelji sa završenom pedagoškom akademijom također intenzivnije slijede sadržaj i strukturu udžbenika u odnosu na učitelje koji su završili sveučilišni studij matematike. 
Tablica 6.

Deskriptivni pokazatelji i testiranje značajnosti razlika u tvrdnjama o individualiziranom pristupu u nastavi s obzirom na titulu nastavnika matematike

\begin{tabular}{|c|c|c|c|c|c|c|}
\hline & & $\mathbf{N}$ & M & SD & $\mathbf{F}$ & $p$ \\
\hline \multirow{3}{*}{$\begin{array}{l}\text { 10.1. Pri usvajanju novoga } \\
\text { gradiva osobno učenicima } \\
\text { objašnjavam gradivo } \\
\text { frontalnim radom.* }\end{array}$} & profesor matematike & 337 & $3,07_{3}$ & 0,56 & \multirow{3}{*}{16,121} & \multirow{3}{*}{0,000} \\
\hline & učitelj matematike & 462 & $3,01_{3}$ & 0,60 & & \\
\hline & $\begin{array}{l}\text { učitelj RN s pojačanim } \\
\text { predmetom matematika }\end{array}$ & 98 & $3,38_{1,2}$ & 0,55 & & \\
\hline \multirow{3}{*}{$\begin{array}{l}\text { 10.2. Pri usvajanju novoga } \\
\text { gradiva učenici samostalno } \\
\text { ili u grupi usvajaju gradivo } \\
\text { iz udžbenika. }\end{array}$} & profesor matematike & 337 & $2,23_{2}$ & 0,62 & \multirow{3}{*}{22,976} & \multirow{3}{*}{0,000} \\
\hline & učitelj matematike & 456 & $2,51_{1,3}$ & 0,66 & & \\
\hline & \begin{tabular}{|l|} 
učitelj RN s pojačanim \\
predmetom matematika \\
\end{tabular} & 98 & $2,18_{2}$ & 0,56 & & \\
\hline \multirow{3}{*}{$\begin{array}{l}\text { 13. Prilikom odabira } \\
\text { zadataka radim } \\
\text { diferencijaciju zadataka } \\
\text { prema sposobnostima } \\
\text { učenika. }\end{array}$} & profesor matematike & 338 & $2,96_{2}$ & 0,65 & \multirow{3}{*}{31,276} & \multirow{3}{*}{0,000} \\
\hline & učitelj matematike & 461 & $3,30_{1,3}$ & 0,59 & & \\
\hline & \begin{tabular}{|l|} 
učitelj RN s pojačanim \\
predmetom matematika
\end{tabular} & 98 & $3,02_{2}$ & 0,64 & & \\
\hline \multirow{3}{*}{$\begin{array}{l}\text { 14. Moji učenici smiju } \\
\text { sami odabrati zadatke iz } \\
\text { udžbenika koje će rješavati } \\
\text { (na satu ili za zadaću). }\end{array}$} & profesor matematike & 338 & $2,29_{2}$ & 0,70 & \multirow{3}{*}{17,306} & \multirow{3}{*}{0,000} \\
\hline & učitelj matematike & 462 & $2,57_{1,3}$ & 0,70 & & \\
\hline & \begin{tabular}{|l|} 
učitelj RN s pojačanim \\
predmetom matematika
\end{tabular} & 97 & $2,36_{2}$ & 0,63 & & \\
\hline
\end{tabular}

Napomena: Brojevi pored prosjeka označavaju usporedbe prema Tukeyovom HSD post hoc testu značajnosti razlika u rezultatima s obzirom na tri kategorije obrazovanja

*Prikaz originalne tvrdnje iz upitnika (negativno korelirana s faktorom); za utvrđivanje pouzdanosti faktora i daljnje analize je rekodirana.

Uvid u zadatke s nacionalnih ispita iz 2007. godine (Institut društvenih znanosti Ivo Pilar, 2007.) otkriva da su zadaci mahom tražili standardno proceduralno znanje iz matematike. Rezultati od Baranović i Štibrić (2009.) ukazuju na dominantan tradicionalan pristup u nastavi matematike u osnovnim i srednjim školama u Hrvatskoj (naglasak je na rješavanju tipičnih zadataka, slušanju i prepisivanju s ploče, dok su matematički koncepti i kritičko mišljenje u drugom planu). Stoga nešto bolji rezultati nacionalnih ispita kod učenika kadra sa završenom pedagoškom akademijom mogu ukazivati i na naglasak na proceduralne zahtjeve u nastavi matematike. S obzirom da se radi o iskusnim učiteljima s dugim stažem, značajke tradicionalne nastave matematike (naglasak na procedurama) kod njih su vjerojatno vrlo izražene. No, na rezultate je sigurno utjecalo i iskustvo učitelja u radu s učenicima (Domović i sur., 2012.), primjerice, njihova primjena individualiziranoga pristupa prema sposobnostima učenika. 


\subsection{Programi za inicijalno obrazovanje učitelja matematike viših razreda osnovne škole}

Razumijevanju rezultata može pomoći i uvid u programe za inicijalno obrazovanje učitelja matematike. Programa za obrazovanje učitelja matematike je mnogo. Svako od četiri sveučilišta u Hrvatskoj na kojima se učitelji matematike trenutno školuju propisuje svoj program, a uz to, programi studija po kojima su se školovali učitelji koji danas rade u školama mijenjali su se kroz godine. Obrazovanje budućih učitelja matematike treba omogućiti stjecanje svih kompetencija (znanja, vještina i stavova) potrebnih za poučavanje matematike u osnovnoj školi. U ovom radu neće se detaljno analizirati svaki pojedini program, nego naglasiti glavne razlike među programima sveučilišnih matematičkih nastavničkih studija i onih na bivšim pedagoškim akademijama, te u svjetlu te analize, pokušati objasniti neke opće razlike u radu i zahtjevima nastavnika.

Prva razlika je svakako trajanje studija. Učitelji sa završenom pedagoškom akademijom imaju višu stručnu spremu i školovali su se dvije godine, dok je sveučilišni studij trajao 4 godine, a današnji nastavnički studiji traju 5 godina. Ti novi, petogodišnji studiji nisu predmetom ove analize jer u trenutku provođenja istraživanja još nije bilo diplomiranih studenata koji su završili petogodišnje programe.

Druga razlika je u sadržajima kolegija. Nastavnički studiji trebaju se sastojati od kolegija vezanih uz znanstvenu disciplinu, odnosno nastavni predmet koji se poučava, kolegija obrazovnih znanosti i metodika, te školske prakse (Pastuović, 2001.).

"U kurikulumu predmetnih nastavnika omjer između sadržaja struke i obrazovnih znanosti s metodikama je oko $70 \%$ prema 30\% (donja granica zastupljenosti obrazovnih znanosti s metodikama je 25\%, što odgovara fondu sati jedne studijske godine)."(Pastuović, 2001.:60).

Borovac (2009.) analizira udio matematičkih i metodičkih kolegija na matematičkim nastavničkim studijima zagrebačkoga Sveučilišta. Rezultati njene analize pokazuju da su u tzv. predbolonjskim programima dominirali matematički kolegiji, dok su metodike s pedagoško-psihološkom grupom kolegija bile ispod preporučenoga udjela. Po takvim programima školovao se veliki broj profesora matematike koji danas rade u školama. Na temelju usporedbe triju generacija programa na Matematičkom odjelu Prirodoslovno-matematičkog fakulteta u Zagrebu ${ }^{13}$, autorica zaključuje da je u starijim programima zastupljenost matematičkih kolegija veća nego u novijima: "vidlivo je kako se udio stručnih kolegija po godinama studija smanjuje, a udio kolegija

13 Prvi analizirani program odnosi se na stari četverogodišnji program dodiplomskoga studija do 2003./2004. za nastavni smjer profesora matematike i informatike. Drugi program noviji je četverogodišnji program koji se realizirao samo u generaciji studenata koja je smjer profesora matematike i informatike upisala u akademskoj godini 2004./2005. Teći program odnosi se na petogodišnji program preddiplomskoga i diplomskoga studija iz edukacije matematike i informatike koji je uveden akademske godine 2005./2006. (Borovac, 2009.). 
obrazounih znanosti i metodika povećava." (Borovac, 2009.:37). Uvid u programe za profesora matematike s ostalih hrvatskih sveučilišta daje slične rezultate ${ }^{14}$.

S druge strane, uvid u programe za učitelje matematike i fizike s bivših pedagoških akademija pokazuje da su ti studenti imali veći udio pedagoško-psihološke grupe predmeta (bar 34\%) u odnosu na matematičke studije, dok je udio matematike i fizike bio oko 55\%. Taj stručni udio bio je manji u odnosu na sveučilišni nastavnički studij matematike.

Spomenute razlike u inicijalnom obrazovanju učitelja matematike mogu se dovesti u vezu s nekim od rezultata istraživanja o upotrebi udžbenika u nastavi matematike. Individualizirani pristup u nastavi i upotreba udžbenika s naglaskom na metodičku interpretaciju kod kadra sa završenom pedagoškom akademijom može se dovesti u vezu s većim udjelom pedagoško-psihološke grupe predmeta u njihovom inicijalnom obrazovanju. S druge strane, učitelji sa završenim sveučilišnim studijima (prof. matematike) pridaju veću pažnju matematičkoj točnosti i korektnosti u udžbeničkim sadržajima. Ovaj način rada može se dovesti u vezu s velikim udjelom matematičkih kolegija, te strogim zahtjevima preciznosti i konciznosti matematičkoga jezika koji su od njih bili traženi tijekom studija na matematičkim fakultetima i odjelima. Njihovo slabije oslanjanje na slijepo slijeđenje udžbenika može se dijelom protumačiti njihovom sigurnošću u matematičko znanje. No, oni su, prema rezultatima ovoga istraživanja, pokazali znatno slabiji interes za individualiziranim pristupom, tj. prilagodbi načina rada prema sposobnostima učenika, u odnosu na kolege s pedagoških akademija.

Učitelji razredne nastave $\mathrm{s}$ pojačanim predmetom matematika u rezultatima nisu se značajno isticali u korištenju udžbenika u odnosu na druge dvije skupine. Veće su razlike bile između ispitanika s titulama učitelja i profesora matematike. Program studija za diplomirane učitelje s pojačanim predmetom matematika bio je vrlo specifičan jer se nije sastojao samo od matematičkih kolegija i od pedagoškopsiholoških kolegija s metodikom matematike, već i od niza ostalih stručnih kolegija potrebnih učiteljima razredne nastave. Taj studij trajao je 8 semestara. No, svakako je zanimljivo primijetiti da je njihov broj sati stručnih matematičkih kolegija otprilike dvostruko veći od broja sati matematičkih kolegija na bivšim pedagoškim akademijama, te otprilike dvostruko manji od broja stručnih matematičkih kolegija na matematičkim nastavničkim studijima ${ }^{15}$.

14 Stariji i tekući programi nalaze se na poveznicama s web stranicama hrvatskih sveučilišta.

15 Izvor: Uvid u nastavne planove za studij učitelja matematike i fizike na bivšoj Pedagoškoj akademiji, za studij učitelja razredne nastave s pojačanim nastavnim predmetom matematika, te za studij profesora matematike na Prirodoslovno-matematičkom fakultetu. 


\section{Zaključak}

Rezultati istraživanja o upotrebi udžbenika u nastavi matematike pokazuju da se ispitani učitelji sa završenom pedagoškom akademijom više oslanjaju na udžbenik u nastavi, te da u nastavi češce prakticiraju individualizirani pristup, odnosno prilagođavaju se sposobnostima, interesima i mogućnostima učenika u nastavi. S druge strane, ispitani učitelji matematike sa završenim sveučilišnim nastavničkim studijem matematike više pažnje posvećuju matematičkoj točnosti u sadržajima udžbenika. Navedene karakteristike mogu se dovesti u vezu sa zahtjevima tijekom njihovih studija, koji su različiti kako duljinom studiranja, tako i sadržajem studijskih programa. Nastavnički matematički studiji (posebice oni stariji) su, naime, u svojim programima naglasak stavljali na matematičke kolegije, dok su u programima bivših pedagoških akademija značajniji udio imali kolegiji koji se odnose na pedagoškopsihološko obrazovanje budućih učitelja.

Inicijalno obrazovanje nalazi se u direktnoj vezi s godinama staža učitelja matematike, s obzirom da učitelji sa završenom bivšom pedagoškom akademijom imaju 30 i više godina staža, dok učitelji s manje staža dolaze sa sveučilišnih studija. Iskustvo u poučavanju i radni staž svakako imaju utjecaja na izvršavanje nastave (Domović i sur., 2012.).

Razlike u načinima poučavanja predmetnih učitelja matematike u hrvatskim osnovnim školama s obzirom na završeni studij i stečenu stručnu spremu, ukazuju na potrebu daljnjega promišljanja o kompetencijama učitelja matematike, kao i na potrebu istraživanja zahtjeva koje različite kategorije učitelja matematike stavljaju pred svoje učenike.

\section{Literatura}

1. Baranović, B. and Štibrić, M. (2009). Math teachers' perceptions of mathematics education in elementary and secondary schools in Croatia. Results of an empirical research, in: Pavleković Margita (Ed.). Second International Scientific Colloquium "Mathematics and Children" - How to Teach and Learn Mathematics. Zagreb: Element.

2. Borovac, M. (2009). Inicijalno obrazovanje nastavnika matematike i informatike, Diplomski rad. Sveučilište u Zagrebu: PMF - Matematički odjel.

3. Domović, V.; Glasnović Gracin, D. i Jurčec, L. (2012). Korištenje matematičkih udžbenika obzirom na spol i godine staža učitelja matematike. Napredak, 153 (2): 187-202

4. Državni zavod za statistiku (2010). Priopćenja i statistička izvješća iz 2006., 2007., 2008., 2009. i 2010. godine. Zagreb: Državni zavod za statistiku. Podaci dostupni na web stranici (www.dzs.hr). Pregledano 19. ožujka 2012.

5. Glasnović Gracin, D. (2011). Requirements in Mathematics Textbooks and PISA Assessment. Doktorska disertacija. Klagenfurt: Alpen-Adria-Universität.

6. Glasnović Gracin, D. i Domović, V. (2009). Upotreba matematičkih udžbenika u nastavi viših razreda osnovne škole. Odgojne znanosti, 2 (18): 297-317. 
7. Institut društvenih znanosti Ivo Pilar (2007). Eksperimentalno vanjsko vrednovanje obrazounih postignuća u osnovnim školama u Republici Hrvatskoj. Zagreb: Institut društvenih znanosti Ivo Pilar. Podaci dostupni na web stranici (http:// dokumenti.ncvvo.hr/Dokumenti_centra/NI2007/izvjestaj-os07.pdf). Pregledano 22. prosinca 2009.

8. Marušić, M. (2002). Struktura nastavnika matematike, u: Mladinić Petar (Ur.). Zbornik radova Šestog susreta nastavnika matematike. Zagreb: Hrvatsko matematičko društvo.

9. Pastuović, N. (2001). Odgoj i obrazovanje - Bijeli dokument o brvatskom obrazovanju. Zagreb: Vlada RH. Pregledano 30. prosinca 2011. Podaci dostupni na web stranici (http://www.see-educoop.net/education in/ pdf/bela knjiga-cro-hrv-t02.pdf).

10. Pepin, B. and Haggarty, L. (2001). Mathematics textbooks and their use in English, French and German classrooms: A way to understand teaching and learning cultures. ZDM - Zentralblatt für Didaktik der Mathematik - The International Journal on Mathematics Education, 33 (5): 158-175.

11. Puževski, V. (2005). Razvojni put Učiteljske akademije u Zagrebu, u: Težak, Dubravka (Ur.). Učiteljska akademija u Zagrebu: 1919 - 2004. Zagreb: Učiteljska akademija.

12. Robitaille, D. F. and Garden. R. A. (Eds.) (1989). The IEA Study of Mathematics II: Context and Outcomes of School Mathematics. Oxford: Pergamon Press.

13. Schmidt, W. H.; McKnight, C. C.; Houang, R. T.; Wang H. C.; Wiley D. E.; Cogan L. S.; Wolfe R. G. (1996). Characterizing Pedagogical Flow. An Investigation of Mathematics and Science Teaching in Six Countries. Dordrecht: Kluwer.

14. Tabachnick, B. G. and Fidell, L. S. (2007). Using multivariate statistics ( $5^{\text {th }}$ edn). Boston: Pearson Education.

15. Težak, S. i Markovac, J. (Ur.) (1971). Pedagoška Akademija Zagreb 1919-1969. Zagreb: Pedagoška Akademija.

16. Zakon o odgoju i obrazovanju u osnovnoj i srednjoj školi, Narodne novine 87 od 2008. 


\title{
Vlatka Domović
}

The Faculty of Teacher Education, University of Zagreb, Croatia e-mail: vlatka.domovic@ufzg.hr

\section{Dubravka Glasnović Gracin}

The Faculty of Teacher Education, University of Zagreb, Croatia e-mail:dubravka.glasnovic@ufzg.hr

Lana Jurčec

The Faculty of Teacher Education, University of Zagreb, Croatia

e-mail: lana.jurcec@ufzg.hr

\section{Initial Teacher Education and the Use of Mathematics Textbooks}

\begin{abstract}
This paper is about the structure of maths teachers in primary schools in Croatia according to their education and also about their usage of maths course books in the classroom, again according to their previous education. The idea was to analyse whether a different education background (the Faculty of Teacher Education graduates, university graduates with a degree in maths) causes teachers to use course books differently. The results show that those teachers who have finished the Faculty of Teacher Education tend to rely more on course books and additional materials ("follow them blindly") while at the same time they approach their students individually and adapt to their needs. These results are also related to teachers' work experience (Domović et al., 2012). University graduates with a degree in maths who have become teachers of mathematics, on the other hand, pay a great deal of attention to precision and accuracy in course books. This could be related to demands made on them during their initial education.
\end{abstract}

Key words: maths classes, maths teachers, course books, primary school, teacher education academy, university studies of maths. 